\title{
Physiological response of grapevines to vascular pathogens: a review
}

\author{
D.C. Mundy ${ }^{1}$ and M.A. Manning ${ }^{2}$ \\ ${ }^{1}$ The New Zealand Institute for Plant E Food Research Limited, Marlborough Wine \\ Research Centre, P.O. Box 845, Blenheim 7240, New Zealand \\ ${ }^{2}$ The New Zealand Institute for Plant \& Food Research Limited, Mt Albert Research \\ Centre, Private Bag 92169, Auckland, New Zealand \\ Corresponding author:dion.mundy@plantandfood.co.nz
}

\begin{abstract}
The successful infection of a grapevine vascular system by a plant pathogen and expression of disease symptoms occur only when the pathogen has overcome the wound response and other defences of the vine. Even when pathogens do successfully infect the vascular system of grapevines, symptom expression is not often observed in the first season. Symptoms may be observed in one year but the same vine can have reduced or no symptoms the following season. Information is presented on physiological stress in association with trunk diseases as one factor that may contribute to symptom expression in vines. A hypothesis of grapevine wound response is proposed as part of the discussion of vine physiological response. Information on individual trunk diseases and physiological interactions is also provided.
\end{abstract}

Keywords grape, wound response, symptoms, stress, trunk disease.

\section{INTRODUCTION}

A complex series of interactions between the causal agent and the grapevine has already occurred before trunk disease symptoms are observed on vines in the vineyard. Many of the steps before the expression of trunk disease symptoms occur in the wood, where they are not easily observed. The time delay between infection and symptom expression with diseases like eutypa dead-arm makes understanding the relationship between disease and symptom expression more difficult.

A successful trunk pathogen has contended with the vine's wound response and other defences. Toxins produced by the pathogen and other pathogenicity factors have had the opportunity to interact with the vine's normal physiological function. During infection and establishment, the pathogen can colonise other tissue as well as/before the vessels (Pascoe \& Cottral 2000). In order to induce vascular disease symptoms, the xylem cell's function is often reduced (Hopkins 1989; Edwards et al. 2007). A vine responding to an infection will have a limited pool of resources to allocate to defence mechanisms. Abiotic stress may limit the vine's ability to allocate resources to infection, resulting in subsequent colonisation of tissues by the pathogen.

Often disease symptoms are both spatially and temporally removed from the initial infection of the vine (Rudelle et al. 2005; Sosnowski et al. 2007). When symptoms are observed in woody plants, the expression may not be the same from 
season to season (Octave et al. 2006; Sosnowski et al. 2007), possibly because of changes in the vine reserves. Host response to vascular infection is a dynamic interaction between host and parasite in which resistance is the rule and susceptibility the exception (Beckman 1964).

\section{PRUNING WOUND RESPONSE}

Using a model system for wound response in flowering plants and investigations of grapevine pathogen interactions, a hypothesis of grapevine response for further investigation has been generated (see below). General wound response of flowering plants has received considerable study and review (Bloch 1941; Bostock \& Stermer 1989). The structure and physiology of grapevines, which may be important to wound response, have also been investigated and summarised (Pratt 1974; Mullins et al. 1992). Understanding grapevine wound response is important, as several grapevine vascular pathogens are believed to enter the vine via mechanical injuries such as pruning wounds (Eutypa lata, Botryosphaeria species, Phaeoacremonium species) (Mundy \& Manning 2010; Rolshausen et al. 2010; Úrbez-Torres \& Gubler 2010). Recent studies of grapevine wounds (Pascoe \& Cottral 2000; Harvey \& Hunt 2006; Sun et al. 2006; Eskalen et al. 2007; Sun et al. 2007; Weber et al. 2007; Sun et al. 2008; Rolshausen et al. 2010; Úrbez-Torres \& Gubler 2010) and the use of wound dressings (Moller \& Kasimatis 1980; Jaspers 2001; John et al. 2005) in relation to grapevine trunk disease pathogens have provided observations for the model proposed.

Plants resist pathogen attack via multilayered constitutive and inducible defences. For example, high lignin production in cell walls has been reported to confer tolerance to E. lata (Rolshausen et al. 2008). When a plant is cut (or mechanically damaged), resulting in disruption to the vascular system, a multi-step wound response is activated (Bloch 1941; Bostock \& Stermer 1989; Hawkins $\&$ Boudet 1996). Wound responses take place at cellular and tissue levels, with the degeneration or necrosis of cells at the wound site providing signals to surrounding healthy cells (Bloch
1941). The wound response signalling pathway shares common components (e.g. jasmonate signals) with those activated following insect and pathogen attack. The rate of response has implications for the disease resistance of the plant (Bostock \& Stermer 1989).

Generalised cell response to wounding includes signalling pathways that are triggered by elicitors, including ion fluxes, oxidative burst and synthesis of signal compounds such as ethylene, salicylic acid and jasmonic acid (Belhadj et al. 2006). The pathogen may act on the elicitor signal pathways, producing toxininduced symptoms remote from the site of production (Valtaud et al. 2009). These defence pathways include reinforcement of plant cell walls, accumulation of phytoalexins and other antimicrobial compounds, and proteins inhibitory or hydrolytically active towards microbes may be induced (Belhadj et al. 2006).

Bostock \& Stermer (1989) described three wound response types in plants, with the most complex being observed in woody perennial stems as well as potato tubers, which have been used as a model system for understanding the response. The response process involves three key steps: (i) the cells adjacent to the wound dying from autolysis, (ii) existing parenchyma cells undergoing redifferentiation and lignosuberization to form a boundary zone with increased physical resistance and (iii) the formation of a suberized wound periderm below the boundary zone as a result of meristematic activity (Bostock \& Stermer 1989). Biochemical changes in individual cells' induced responses to pathogen attack and/or mechanical wounding include the accumulation of phenols, phytoalexin production, synthesis of hydrolytic enzymes, and cell wall reinforcement with the phenolic polymers suberin and/or lignin (Hawkins \& Boudet 1996).

Within the vascular tissue, the vine responds to wounding of the vessels by the production of tyloses. Tyloses form when the protoplasmic membrane of the parenchyma cells next to the xylem cells extends into the vessel via the pit to form a balloon-like structure that, in grapes, eventually becomes lignified (Pratt 1974). When 
a large number of tyloses form, they can block the vessel. The formation of tyloses and other responses occur over time in response to the initial wounding event. Hawkins \& Boudet (1996) developed a model system for studying the gene expression response to mechanical wounding in flowering plants and used it to investigate changes over time (1-7 days) in lignin and suberin deposition.

The formation of tissue impervious to water and microorganism penetration is a common feature of wound response of woody plants associated with resistance to pathogens (Bostock \& Stermer 1989). When physical barriers are produced, this is often in association with production of anti-microbial phenolics (Del Rio et al. 2001; Treutter 2005) and a reduction in the availability of simple sugars (and other nutrients) at the wound site (Bostock \& Stermer 1989).

\section{Unique features of grapevines}

Grapevine xylem has some distinct physiological and structural features that distinguish it from other flowering plants. In grapevines, the secondary xylem is described as diffuse-porous with ladder-like thickening surrounded by living xylem parenchyma (Mullins et al. 1992). Septate fibres with bordered pits are the predominant xylem elements (Mullins et al. 1992). The xylem cells have been observed to respond to wounding with seasonal differences in the mechanism for sealing grapevine trunk xylem, with gel (temporary) closers produced in winter and more permanent tyloses in summer (Sun et al. 2008). Most plants produce either gels or tyloses (Sun et al. 2008). In grapevines a single ring of xylem is produced each year, but the vessels can remain functional for up to 7 years (Mullins et al. 1992). Most grapevine xylem vessels become inactive because of tylose formation after 2-3 years (Pratt 1974), rather than after a single season as is observed in other woody plants.

\section{Hypothesis of grapevine wound healing}

When a grapevine is cut, the vine responds as a woody plant (described above), cells die next the wound, signals are sent to the rest of the tissue and undifferentiated cells start to form a periderm. Within the vessels, gels or tyloses form depending on the season. For a large cut to the vine, up to 7 years of xylem may need to be sealed to prevent water loss and microbial entry. Phenolic compounds are deposited at the wound, and over time the wound becomes less susceptible to infection by trunk pathogens. Investigations have indicated that the timing of the wounding event can determine the length of the wound susceptibility.

\section{PHYSIOLOGICAL STRESS AND SYMPTOM EXPRESSION}

Interactions between disease symptom expression and grapevine stress have been suggested as one possible explanation for inconsistent visual symptoms for some vascular diseases. In seasons when growth of the vine is not inhibited by abiotic factors, foliar symptoms of E. lata in grapes are not often observed or are reduced in severity (Sosnowski et al. 2007). In seasons when vines experience abiotic stresses, individual vine reserves may influence symptom expression.

If vine stress does have a role in symptom expression, then the mechanism of this reaction needs to be considered. Although grapevines are grown in a highly managed production system, they are still subject to the ambient climate of the region. Some of the management methods used, such as controlled irrigation or removal of leaf area, may produce stress within the vine, which can be further exacerbated by environmental conditions. A range of abiotic stresses may occur in vineyards; defoliation, freezing stress and nutrient stress are factors that have been reported to predispose forest trees to disease symptom expression comparable to water stress for canker diseases (Desprez-Loustau et al. 2006).

\section{Drought/water stress}

Desprez-Loustau et al. (2006) proposed four main types of drought-disease interactions that could be expected in forest trees. The summary below has been broadened to include all abiotic stresses:

1. Direct effects of abiotic stress on the pathogen. 
2. Indirect effects of abiotic stress on the pathogen through other community interactions (such as an increase or decrease of naturally occurring biological control agents).

3. Host predisposition, i.e. the effect of abiotic stress on the host physiology leading to susceptibility.

4. Multiple stresses, i.e. the combined effects of infection and abiotic stress on tree physiology.

Drought-disease interactions in forest trees have been reviewed, with a majority of published studies referring to a positive association between drought and disease (Desprez-Loustau et al. 2006). When investigating drought and disease interactions for grapes, it is important to consider symptoms and timing of water stress. The symptoms of trunk diseases and water stress are often related, with both resulting in reduced movement of water in the xylem.

More than half the reviewed studies of forest tree drought-disease interactions were for canker/ die-back pathogens such as Botryosphaeria (Desprez-Loustau et al. 2006), which correspond with the type of diseases that are commonly grouped as trunk diseases of grapes. In the case of Xylella spp. infection, the gene transcription response of vines is similar to responses to drought stress (Choi et al. 2010). As vascular diseases are found in the vessels and vine responses to the pathogen involve blocking infected vessels, aggregates and tyloses can physically block a sufficient number of vessels to prevent xylem flow (Martelli et al. 1986). For Pierce's disease, the observed water stress symptoms are the result of xylem occlusions (Hopkins 1989). Beckman (1964) noted that physiological changes in the plant, such as increased respiration and changes in water balance (reduced supply), result in wilting due to lack of water, rather than toxins produced by the trunk diseases.

However, water stress or drought may also predispose a vine to disease development (Ferreira et al. 1999) or lead to a more rapid exhaustion of the vine as a result of additive deleterious effects, as reported for forest trees
(Desprez-Loustau et al. 2006). Extended drought conditions have been reported to exacerbate the development of Pierce's disease, as water-stressed vines in vineyard conditions appear more susceptible than well watered vines (Hopkins 1989).

When considering water stress, the timing of stress mayalso be important. Foryoung grapevines already infected with Phaeoacremonium chlamydosporum, water stress significantly increased vine death (Ferreira et al. 1999). However, in contrast, vines that had been water stressed and then infected with Neofusicoccum luteum had a reduction in shoot die-back lesion length at $25 \%$ field capacity compared with 50 and 75\% field capacity (Amponsah 2011). DesprezLoustau et al. (2006) reported that many of the positive drought-disease interactions involved increased severity or impact of the disease rather than increased incidence of infection. For the N. luteum experiment (Amponsah 2011), existing stress may have reduced the susceptibility of tissues to infection via the blocking of vessels or other mechanisms, reducing the spread of the pathogen following infection.

\section{Limited resources}

For plants, a "trade-off" exists between growth and defence-related metabolism (Treutter 2005). When defence compounds are produced, they use plant resources including amino acids, carbohydrates and nutrients. The removal of these resources from the vine's pool of reserves can then have follow-on effects on plant growth. One of the typical symptoms associated with diseases such as eutypa dead-arm is reduced vine vigour. Reduced vigour may be the result of diversion of resources to a defence response or a knocking out of part of the vine's infrastructure.

The induction of flavonoid biosynthesis and accumulation as part of a defence response has been shown to be limited by the availability of carbon, energy or other resources (Treutter 2005). Amino acids within the vine may be used for the production of phenolic compounds in response to infection with botrytis bunch rot. However, the same amino acids are also used in a 
number of plant biochemical pathways (Mundy 2008). If a vine has already experienced water stress and allocated other amino acids to proline production to maintain osmotic pressure (Keller 2005), then less raw material will be available to produce flavonoids as part of a plant defence.

Vines infected with E. lata have reduced starch storage in the xylem parenchyma cells and rays compared with healthy vines (Rudelle et al. 2005). Rudelle et al. (2005) have suggested high metabolic activity is associated with observed secretory defence responses involving well developed and more numerous mitochondria. A high metabolic activity could account for the reduced starch storage. Eutypa lata can produce a polypeptide fraction that induces changes in grape leaves, resulting in reduced assimilation of the products of photosynthesis and lower leaf respiration (Octave et al. 2006), which may result in further reduction in vine reserves.

Vines with Phaeomoniella chlamydospora had reduced carbohydrate reserves compared to the control vines during winter dormancy, even if symptoms were not expressed, and an overall loss of plant vigour (Petit et al. 2006), indicating changes in vine resources as a result of infection.

Nutrient supply may be important for disease response. In strawberries (Walter et al. 2008) and grapes (Elmer \& Reglinski 2006), calcium has been associated with cell wall integrity and resistance to fungal penetration. Increases in vine uptake of calcium ions during Pierce's disease infection, as part of the plant's defence system, have been reported (Xu et al. 2003). Magnesium ions have been reported as a possible factor for detoxification of fungal toxins produced by E. lata (Colrat et al. 1999). Changes in nutrient reserves within tissues may also be related to symptom expression, with the suggestion of a link between toxic amounts of macronutrients $\left(\mathrm{Ca}^{++}\right.$and $\left.\mathrm{Mg}^{++}\right)$in the petioles and leaf symptom expression in Pierce's disease (Xu et al. 2003).

\section{Temperature/seasonal differences}

Increased rates for wound healing later in the pruning season (late winter to early spring) have been reported for grapevines. Reported susceptibility of grapevine pruning wounds to infection by E. lata during this late pruning time was lower than that of vines pruned early in the dormant season (Munkvold \& Marois 1995). These observations may be linked to the reported seasonal differences in grapevine wound response of tyloses or gum formation (Sun et al. 2008). Tyloses and gums have different chemical and physical characteristics, and $\mathrm{R}$ genes that allow a pathogen to overcome one set of wound responses may not be effective against the other. Seasonal differences in infection and susceptibility have been reported for E. lata (Petzoldt et al. 1981; Munkvold \& Marois 1995; Chapuis et al. 1998) and botryosphaeria canker (Úrbez-Torres \& Gubler 2010). However, Chapuis et al. (1998) suggested that infection may be linked to temperature, with E. lata growing well at low temperatures and other microorganisms being suppressed. Temperature conditions can also influence the plant's growth, with climatic conditions that are conducive to vigorous vine growth in spring reported to reduce foliar symptoms of E. lata infection (Sosnowski et al. 2007).

\section{TRUNK DISEASES AND POSSIBLE PATHOGENICTY FACTORS}

The grapevine wound response is effective in stopping most pathogens from entering and establishing in the vine (non-host resistance (Agrios 2005)). In order to be effective pathogens of grapevines, the casual organisms need characteristics that allow them to succeed under conditions that are not conducive to other pathogens. The vessels of grapevines are a nutrient-poor environment for the growth of microorganisms (Valtaud et al. 2009; Ciraulo et al. 2010) but do provide a pathway for movement within the trunk. The successful pathogens of the grapevine vascular system require one or more virulence genes to operate in this grapevine tissue. Researchers have studied different vascular pathogens of grapes to obtain an understanding of the processes involved in successful infection. Histopathology of infections in vine wood has been reported for a range of vascular 
pathogens including Botryosphaeria stevensii (Whitelaw-Weckert et al. 2006), Lasiodiplodia theobromae (Úrbez-Torres \& Gubler 2010), Neofusicoccum parvum (Úrbez-Torres \& Gubler 2010), Phaeomoniella chlamydospora (formerly Phaeoacremonium chlamydosporum) (Pascoe \& Cottral 2000; Whiteman et al. 2002; Whiteman et al. 2007) and Xylella fastidiosa (Roper et al. 2007; Ciraulo et al. 2010).

\section{Botryosphaeria canker}

Pycnidiospores are dispersed by rain splash, spreading botryosphaeria canker via the infection of exposed xylem of pruning wounds (Úrbez-Torres \& Gubler 2010). The importance of wound age for the infection of botryosphaeriaceous species has been reported, with no conidial infections of Neofusicoccum luteum 14 days after wounding (Amponsah et al. 2009). These results are consistent with studies of wound periderms (cork barriers) (Bostock \& Stermer 1989), although the formation of a periderm was not investigated for $N$. luteum. Both duration of susceptibility of pruning wound and effect of pruning time on susceptibility of fresh wounds to infection by Lasiodiplodia theobromae and Neofusicoccum parvum have been studied in California (Úrbez-Torres \& Gubler 2010). In the artificially-inoculated Californian vineyard studies, pruning vines in late, rather than early, winter resulted in reduced percentage of botryosphaeria canker infections. The mechanism for differences in infection rates is yet to be determined.

\section{Eutypa dead-arm}

The observations of Rudelle et al. (2005) suggest that vessel-associated cells are very important for the vine's defence against trunk diseases and these cells can be activated remotely from the site of infection by toxin/signalling compounds conducted in the xylem. Vessel-associated cells appear to slow the progress of E. lata even in susceptible cultivars. However, the anatomy of the vine prevents this mechanism from completely protecting the vessels, as vessel-associated cells do not form a complete ring around the conducting xylem (Rudelle et al. 2005). Vesselassociated cells have structural analogies to phloem companion cells, but have lignified walls, and no plasmodesmata interface with the vessel element (Fromard et al. 1995).

Sosnowski et al. (2007) hypothesised that climate is one factor that may influence the expression of foliar symptoms of E. lata in grapes. They developed a conceptual model that predicts expression of symptoms based on winter rainfall and spring temperatures in conjunction with initial observations of disease severity. Additional study is required to elucidate how the climate influences the fungal pathogen or the vine response, leading to symptom expression (Sosnowski et al. 2007). In forest trees it has been observed that, while drought conditions may be negatively correlated to successful new fungal infections, they can be positively related to existing endophytes and saprophytes becoming damaging pathogens in plants predisposed by stress (Desprez-Loustau et al. 2006). While there are models for the infection stage of many diseases, modelling of climate and other life cycle stages may allow better management of vascular diseases that are already present in vineyards.

\section{Esca complex, including Phaeomoniella chlamydospora}

Pascoe \& Cottral (2000) investigated Phaeomoniella chlamydospora infection of tissue cultured Chardonnay plants and observed infection of the xylem parenchyma cells, which then moved into the adjacent vascular vessels. The pathogen hyphae were observed to enter the vessels at the sites of tylose formation. Hyphae travelled along vessels and phenolic compound accumulations in the trunk tissues were not always associated with heavy concentrations of hyphae. As "goo" and other phenolic compounds were often some distance from the site of infection, a toxin or some other signalling compound may be involved, possibility explaining why P. chlamydospora is not always isolated from the sites where "black goo" is observed (Pascoe \& Cottral 2000). Later research from the same group showed that in vines infected with 
P. chlamydospora, blockages of the xylem function could be significantly higher (16\%) than the percentage of vessels with "goo" symptoms (1\%) (Edwards et al. 2007).

Esca disease symptoms include distinctive tiger-striped leaves with orange inter-vein regions (Mundy \& Manning 2010). The observed foliar symptoms are distant from the primary site of infection (Valtaud et al. 2009). The leaf symptoms of esca are probably the result of extensive cellular oxidation following a decrease in leaf glutathione content (Valtaud et al. 2009). Intracellular structural damage can be detected in leaf cells before visible symptoms appear, suggesting modification of plant metabolism in the early stages of symptom expression (Valtaud et al. 2009).

\section{Pierce's disease}

The bacterium Xylella fastidiosa is the causal agent of Pierce's disease. The physiological effects of this disease have been the focus of considerable study following the arrival of an insect vector (glassy winged sharpshooter - Homalodisca vitripennis) into Californian vineyards. As with many of the trunk diseases, infections by $X$. fastidiosa can occur remotely in time and space from the site of symptom expression. Investigations have shown that vines often harbour high titres of $X$. fastidiosa before visual symptom expression (Choi et al. 2010). The bacteria effectively bypass the vine wound response when injected directly into the xylem from the foregut of the glassy winged sharpshooter (Redak et al. 2004). When infections do occur, $X$. fastidiosa has been shown to change the nutrient content of leaves before and during symptom expression (Xu et al. 2003).

\section{CONCLUSIONS}

The successful trunk disease pathogens of grapevines have evolved with the host plant and have mechanisms to overcome at least some of the host defences. To develop better control of these diseases, the interactions between the plant pathogen and the environment must first be understood, so that conditions can be manipulated in favour of the vine. In summary:

1. Grapevines appear to have the same basic wound healing mechanism as most woody plants.

2. The speed of wound response depends on timing of wounding.

3. Wound susceptibility decreases as wounds age.

4. Disease symptom expression can be influenced by abiotic stress.

5. Vines have limited resources/reserves to respond to biotic or abiotic stress.

6. Physical structures such as vesselassociated cells or thickened lignin deposits may be important for varietal tolerance of disease.

Understanding how the physiology of vines influences pathogen infection and expression will allow the development of better management and control strategies for grapevine trunk diseases in New Zealand and internationally.

\section{ACKNOWLEDGEMENTS}

This paper was developed from research funded by the New Zealand Foundation for Research, Science and Technology (Contract CO6X0810), the Ministry of Agriculture and Forestry Sustainable Farming Fund, New Zealand Winegrowers and the Marlborough Wine Research Centre. We would also like to thank Dr Ian Horner, Dr Robert Beresford, Dr Tony Reglinski, Dr Peter Minchin and Dr Stephen Hoyte for their comments on the manuscript.

\section{REFERENCES}

Agrios GN 2005. Plant pathology. Academic Press, San Diego, CA. 922 p.

Amponsah NT 2011. Epidemiology of the Botryosphaeriaceous species associated with grapevines in New Zealand. PhD thesis, Lincoln University, Christchurch, New Zealand. $252 \mathrm{p}$.

Amponsah NT, Jones EE, Ridgway HJ, Jaspers MV 2009. Factors that affect the infection of grapevine tissues with Botryosphaeria species (Meeting abstract). Phytopathologia Mediterranea 48: 176. 
Beckman CH 1964. Host responses to vascular infection. Annual Review of Phytopathology 2: 231-252.

Belhadj A, Saigne C, Telef N, Cluzet S, Bouscaut J, Corio-Costet MF, Mérillon JM 2006. Methyl jasmonate induces defense responses in grapevine and triggers protection against Erysiphe necator. Journal of Agricultural and Food Chemistry 54: 9119-9125.

Bloch R 1941. Wound healing in higher plants. The Botanical Review 7: 110-146.

Bostock RM, Stermer BA 1989. Perspectives on wound-healing in resistance to pathogens. Annual Review of Phytopathology 27: 343-371.

Chapuis L, Richard L, Dubos B 1998. Variation in susceptibility of grapevine pruning wound to infection by Eutypa lata in south-western France. Plant Pathology 47: 463-472.

Choi HK, da Silva FG, Lim HJ, Iandolino A, Seo YS, Lee SW, Cook DR 2010. Diagnosis of Pierce's disease using biomarkers specific to Xylella fastidiosa rRNA and Vitis vinifera gene expression. Phytopathology 100: 1089-1099.

Ciraulo MB, Santos DS, Rodrigues AC, de Oliveira MV, Rodrigues T, de Oliveira RC, Nunes LR 2010. Transcriptome analysis of the phytobacterium Xylella fastidiosa growing under xylem-based chemical conditions. Journal of Biomedicine and Biotechnology 2010: 1-18.

Colrat S, Deswarte C, Latché A, Klaébé A, Bouzayen M, Fallot J, Roustan JP 1999. Enzymatic detoxification of eutypine, a toxin from Eutypa lata by Vitis vinifera cells: partial purification of an NADPH-dependent aldehyde reductase. Planta 207: 544-550.

Del Rio JA, Gonzalez A, Fuster MD, Botia JM, Gomez P, Frias V, Ortuño A 2001. Tylose formation and changes in phenolic compounds of grape roots infected with Phaeomoniella chlamydospora and Phaeoacremonium species. Phytopathologia Mediterranea 40 (Suppl.): S394-S399.

Desprez-Loustau ML, Marcais B, Nageleisen LM, Piou D, Vannini A 2006. Interactive effects of drought and pathogens in forest trees. Annals of Forest Science 63: 597-612.
Edwards J, Pascoe IG, Salib S 2007. Impairment of grapevine xylem function by Phaeomoniella chlamydospora infection is due to more than physical blockage of vessels with 'goo'. Phytopathologia Mediterranea 46: 87-90.

Elmer PAG, Reglinski T 2006. Biosuppression of Botrytis cinerea in grapes. Plant Pathology 55: 155-177.

Eskalen A, Feliciano AJ, Gubler WA 2007. Susceptibility of grapevine pruning wounds and symptom development in response to infection by Phaeoacremonium aleophilum and Phaeomoniella chlamydospora. Plant Disease 91: 1100-1104.

Ferreira JHS, van Wyk PS, Calitz FJ 1999. Slow dieback of grapevine in South Africa: stress-related predisposition of young vines for infection by Phaeoacremonium chlamydosporum. South African Journal of Enology and Viticulture 20: 43-46.

Fromard L, Babin V, Fleurat-Lessard P, Fromont JC, Serrano R, Bonnemain JL 1995. Control of vascular sap $\mathrm{pH}$ by the vessel-associated cells in woody species. Plant Physiology 108: 913-918.

Harvey IC, Hunt JS 2006. Penetration of Trichoderma harzianum into grapevine wood from treated pruning wounds. New Zealand Plant Protection 59: 343-347.

Hawkins S, Boudet A 1996. Wound-induced lignin and suberin deposition in a woody angiosperm (Eucalyptus gunnii; Hook.): histochemistry of early changes in young plants. Protoplasma 191: 96-104.

Hopkins DL 1989. Xylella fastidiosa: Xylemlimited bacterial pathogen of plants. Annual Review of Phytopathology 27: 271-290.

Jaspers MV 2001. Sensitivity of Phaeomoniella chlamydospora to fungicides in vitro. New Zealand Plant Protection 54: 225-228.

John S, Wicks TJ, Hunt JS, Lorimer MF, Oakey $\mathrm{H}$, Scott ES 2005. Protection of grapevine pruning wounds from infection by Eutypa lata using Trichoderma harzianum and Fusarium lateritium. Australasian Plant Pathology 34: 569-575. 
Keller M 2005. Deficit irrigation and vine mineral nutrition. American Journal of Enology and Viticulture 56: 267-283.

Martelli GP, Graniti A, Ercolani GL 1986. Nature and physiological effects of grapevine diseases. Cellular and Molecular Life Sciences 42: 933-942.

Moller WJ, Kasimatis AN 1980. Protection of grapevine pruning wounds from eutypa dieback. Plant Disease 64: 278-280.

Mullins MG, Bouquet A, Williams LE 1992. Biology of the grapevine. Cambridge University Press, Cambridge, England. 239 p.

Mundy DC 2008. A review of the direct and indirect effects of nitrogen on botrytis bunch rot in wine grapes. New Zealand Plant Protection 61: 306-310.

Mundy DC, Manning MA 2010. Ecology and management of grapevine trunk diseases in New Zealand: a review. New Zealand Plant Protection 63: 160-166.

Munkvold GP, Marois JJ 1995. Factors associated with variation in susceptibility of grapevine pruning wounds to infection by Eutypa lata. Phytopathology 85: 249-256.

Octave S, Amborabe BE, Fleurat-Lessard P, Berges T, Roblin G 2006. Modifications of plant cell activities by polypeptides secreted by Eutypa lata, a vineyard fungal pathogen. Physiologia Plantarum 128: 103-115.

Pascoe I, Cottral E 2000. Developments in grapevine trunk diseases research in Australia. Phytopathologia Mediterranea 39: 68-75.

Petit AN, Vaillant N, Boulay M, Clement C, Fontaine F 2006. Alteration of photosynthesis in grapevines affected by esca. Phytopathology 96: 1060-1066.

Petzoldt CH, Moller WJ, Sall MA 1981. Eutypa dieback of grapevine: Seasonal differences in infection and duration of susceptibility of pruning wounds. Phytopathology 71: 540543.

Pratt C 1974. Vegetative anatomy of cultivated grapes: A review. American Journal of Enology and Viticulture 25: 131-150.
Redak RA, Purcell AH, Lopes JRS, Blua MJ, Mizell III RF, Andersen PC 2004. The biology of xylem fluid-feeding insect vectors of Xylella fastidiosa and their relation to disease epidemiology. Annual Review of Entomology 49: 243-270.

Rolshausen PE, Greve LC, Labavitch JM, Mahoney NE, Molyneux RJ, Gubler WD 2008. Pathogenesis of Eutypa lata in grapevine: Identification of virulence factors and biochemical characterization of cordon dieback. Phytopathology 98: 222-229.

Rolshausen PE, Urbez-Torres JR, Rooney-Latham S, Eskalen A, Smith RJ, Gubler WD 2010. Evaluation of pruning wound susceptibility and protection against fungi associated with grapevine trunk diseases. American Journal of Enology and Viticulture 61: 113-119.

Roper MC, Greve LC, Warren JG, Labavitch JM, Kirkpatrick BC 2007. Xylella fastidiosa requires polygalacturonase for colonization and pathogenicity in Vitis vinifera grapevines. Molecular Plant-Microbe Interactions 20: 411-419.

Rudelle J, Octave S, Kaid-Harche M, Roblin G, Fleurat-Lessard P 2005. Structural modifications induced by Eutypa lata in the xylem of trunk and canes of Vitis vinifera. Functional Plant Biology 32: 537-547.

Sosnowski MR, Shtienberg D, Creaser ML, Wicks TJ, Lardner R, Scott ES 2007. The influence of climate on foliar symptoms of Eutypa dieback in grapevines. Phytopathology 97: 1284-1289.

Sun Q, Rost TL, Matthews MA 2006. Pruninginduced tylose development in stems of current-year shoots of Vitis vinifera (Vitaceae). American Journal of Botany 93: 1567-1576.

Sun Q, Rost TL, Matthews MA 2008. Woundinduced vascular occlusions in Vitis vinifera (Vitaceae): Tyloses in summer and gels in winter. American Journal of Botany 95: 14981505.

Sun Q, Rost TL, Reid MS, Matthews MA 2007. Ethylene and not embolism is required for wound-induced tylose development in stems of grapevines. Plant Physiology 145: 1629-1636. 
Treutter D 2005. Significance of flavonoids in plant resistance and enhancement of their biosynthesis. Plant Biology 7: 581-591.

Úrbez-Torres JR, Gubler WD 2010. Susceptibility of grapevine pruning wounds to infection by Lasiodiplodia theobromae and Neofusicoccum parvum. Plant Pathology 60: 261-270.

Valtaud C, Foyer CH, Fleurat-Lessard P, Bourbouloux A 2009. Systemic effects on leaf glutathione metabolism and defence protein expression caused by esca infection in grapevines. Functional Plant Biology 36: 260-279.

Walter M, Braithwaite B, Smith BJ, Langford GI 2008. Nutrient nitrogen management for disease control in strawberry. New Zealand Plant Protection 61: 70-79.

Weber EA, Trouillas FP, Gubler WD 2007. Double pruning of grapevines: A cultural practice to reduce infections by Eutypa lata. American Journal of Enology and Viticulture 58: 61-66.
Whitelaw-Weckert MA, Sergeeva V, Priest MJ 2006. Botryosphaeria stevensii infection of Pinot Noir grapevines by soil-root transmission. Australasian Plant Pathology 35: 369.

Whiteman SA, Jaspers MV, Stewart A, Ridgway HJ 2002. Detection of Phaeomoniella chlamydospora in soil using species-specific PCR. New Zealand Plant Protection 55: 139145.

Whiteman SA, Stewart A, Ridgway HJ, Jaspers MV 2007. Infection of rootstock mothervines by Phaeomoniella chlamydospora results in infected young grapevines. Australasian Plant Pathology 36: 198-203.

Xu X, Lu J, French MF, Engel ME 2003. Roles of macronutrients in Pierce's disease development of grapevines. Proceedings of the Florida State Horticultural Society 116: 10-12. 